Плодоводство и виноградарство Юга России № 59(5), 2019 г.

УДК 634.85:631.524.7/.811.98:632.654/.951

UDC 634.85:631.524.7/.811.98:632.654/.951

DOI 10.30679/2219-5335-2019-5-59-78-91

DOI 10.30679/2219-5335-2019-5-59-78-91

РЕГЛАМЕНТ ПРИМЕНЕНИЯ

БИОЛОГИЧЕСКОГО

ПРЕПАРАТА «ПФКЛЕРОС»

С КОМПЛЕКСНЫМ ДЕЙСТВИЕМ

НА ВИНОГРАДНИКАХ

ЮЖНОГО БЕРЕГА КРЫМА

Бейбулатов Магомедсайгит Расулович

д-р с.-х. наук

начальник отдела агротехники

Буйвал Роман Алексеевич

канд. с.-х. наук

научный сотрудник

отдела агротехники

Тихомирова Надежда Александровна

канд. с.-х. наук

ст. научный сотрудник

отдела агротехники

Урденко Наталия Александровна

канд. с.-х. наук

ст. научный сотрудник

отдела агротехники

Федеральное государственное

бюджетное учреждение науки

«Всероссийский национальный

научно-исследовательский институт

виноградарства и виноделия

«Mагарач» $P A H »$,

Ялта, Республика Крым, Россия

Эффективность защитных мероприятий в виноградарстве в большей степени зависит от своевременности их проведения, правильности выбранного срока обработки насаждений, схемы опрыскиваний, инфекционного фона, антирезистентной стратегии применения препаратов.

В данной статье представлены результаты двухлетнего изучения возможности и эффективности применения препарата «ПФКлерос» на техническом сорте винограда Шардоне, 1977 года посадки, в условиях Южного берега Крыма. В исследовании использовались

\section{APPLICATION REGIME FOR «PFKLEROS» BIOLOGICAL PREPARATION WITH COMPLEX ACTION IN THE VINEYARDS OF CRIMEA SOUTHERN COAST}

Beybulatov Magomedsaigit Rasulovich Dr. Sci. Agr.

Head of Agrotechnology Department

Buival Roman Alekseyevich

Cand. Agr. Sci.

Research Associate

of Agrotechnology Department

Tikhomirova Nadezhda Aleksandrovna Cand. Agr. Sci.

Senior Research Associate

of Agrotechnology Department

Urdenko Natalia Alexandrovna

Cand. Agr. Sci.

Senior Research Associate

of Agrotechnology Department

Federal State

Budget Scientific Institution

«All-Russian National

Research Institute

of Viticulture and Winemaking

«Magarach» RAS»,

Yalta, Republic of the Crimea, Russia

The effectiveness of protective measures in the viticulture largely depends on the timeliness of their implementation, the correctness of the chosen processing time of plantations, schemes of spraying, infectious background, antiresistant strategiy for drugs use. This article presents the results of a two-year study on possibility and efficiency of «PFKleros» application for technical grape variety of Chardonnay, 1977 landing, in the conditions of Southern coast of Crimea. In the study the well-known viticulture 
общепринятые в виноградарстве методики. Установлено, что при применении испытуемого препарата «ПФКлерос», в случае с трёхкратной обработки виноградника, численность паутинного клеща, в зависимости от нормы применения, снижается до 85,7-69,2 \%, что соответствует результатам, полученным при использовании эталонного препарата Золон. Биологическая эффективность системы защиты, включающая три обработки виноградных растений против оидиума, составила 7,5 \%, что соответствует результатам, полученным при использовании эталонного препарата Топаз. Результаты проведенных исследований показали, что обработки препаратом «ПФКлерос» способствуют увеличению урожая винограда сорта Шардоне в среднем на 38,5-50,0 \%, при этом прибавка урожая составляет 2,0-2,6 т/га. Подтверждено положительное влияние изучаемого препарата на показатели качества винограда: массовая концентрация сахаров в соке ягод повысилась от 2,4 до 7,3\%. Установлено, что обработки препаратом «ПФКлерос» активизируют ростовые процессы виноградных растений. Положительное действие изучаемого препарата выразилось в увеличении средней длины побегов на 13,3-25,7 \%, площади листовой поверхности - на 14,8-24,4 \% и степени вызревания побегов на 9,1-18,9 \% по сравнению с контролем (растения без обработки).

Ключевые слова: ФУНГИЦИДНОАКАРИЦИДНЫЙ ПРЕПАРАТ, БИОЛОГИЧЕСКАЯ ЭФФЕКТИВНОСТЬ, УРОЖАЙ ВИНОГРАДА, КАЧЕСТВЕННЫЕ ПОКАЗАТЕЛИ, ВЫЗРЕВАНИЕ ПРИРОСТА methods are used. It was established that triple vineyard treatment with the tested preparation «PFKleros» reduces Tetranychidae population by $69.2-85.7 \%$, depending on the application rate, which is consistent with the results obtained under application of standard preparation Zolon. The biological effectiveness of the protection system engaging triple treatment against oidium made $7.5 \%$, which is consistent with the results obtained under application of standard preparation Topaz. The results of research showed that treatments with «PFKleros» preparation on average increase in the harvest of Chardonnay grapes by $38.5-50.0 \%$, where as the yield surplus is estimated at 2.0-2.6 t/ha. The positive effect of the studied preparation on the quality of Chardonnay grapes was confirmed, as demonstrated by increased from 2.4 up to $7.3 \%$ sugar mass concentration in the berry juice. It was established that treatments with «PFKleros» preparation catalyze growth processes. The positive effect of the studied preparation was reflected in the increased by 13.3-25.7\% shoot length on overage, increased by $14.8-24.4 \%$ in leaf surface and increased by $9.1-18.9 \%$ in extent of shoot lignification, as compared to control (the plants without of treatment).

Key words: ANTIFUNGALACARICIDAL PREPARATION, BIOLOGICAL EFFECTIVENESS, GRAPE HARVEST, QUALITATIVE INDICATORS, SHOOT LIGNIFICATION

Введение. В современных условиях интенсификации сельского хозяйства проблема сохранения урожая винограда в условиях напряжённости абиотических и биотических факторов среды остаётся актуальной [1-8]. 
Плодоводство и виноградарство Юга России № 59(5), 2019 г.

В целях снижения потерь, которые в среднем составляют 30-37 \%, необходимо совершенствовать существующую систему защиты промышленных виноградников. Производство стабильных урожаев возможно лишь при эффективной системе защиты от вредных объектов. Одной из задач защиты растений на современном этапе является усовершенствование существующих агротехнических и защитных мероприятий, входящих в технологию возделывания культуры, повышение их экологической безопасности и эффективности [9-15]. Эффективность защитных мероприятий в большей степени зависит от своевременности их проведения, правильности выбранного срока обработки, схемы опрыскиваний, инфекционного фона, антирезистентной стратегии применения препаратов.

Современный ассортимент химических препаратов расширяется за счёт появления аналогов отечественного производства, что даёт возможность маневрировать в использовании средств защиты, отличающихся небольшими нормами расхода и умеренной токсической нагрузкой [16-19].

На основании вышеизложенного актуальными и обоснованными являются исследования по эффективности применения нового фунгицидноакарицидного препарата «ПФКлерос» на культуре винограда в условиях Южного берега Крыма.

Объекты и методы исследований. Препарат «ПФКлерос» (ПСК 25 \% водный раствор) обладает рядом преимуществ по сравнению с традиционно применяемыми средствами защиты растений подобного спектра действий: двойное действие препарата (фунгицид и акарицид); высокая эффективность. Исследования проводились в период с 2016 по 2017 год сотрудниками лаборатории агротехнологий винограда ФГБУН «ВННИИВиВ «Магарач» РАН» на плодоносящих виноградниках ГУП РК «ПАО «Массандра», филиал «Гурзуф», на техническом сорте Шардоне 1997 года посадки. Привит на подвойный сорт - Берландиери х Рипариа Кобер 5ББ. 
Схема посадки 3,0 х 1,0 м, в стандартном ряду 100 кустов. Использовались общепринятые в виноградарстве методики. Статистическая обработка данных проводилась по Доспехову [20].

Почвенный покров на виноградниках представлен коричневыми почвами на слабо щебнистых тяжелосуглинистых отложениях. Мощность гумусового горизонта 50-60 см. Гумусовые горизонты Н и Нр перемешаны в результате плантажной вспашки, коричнево-бурой окраски; щебень, камни более 30 \%. В плантажный слой вовлечён и нижний переходной горизонт ph. Почвообразующая порода - суглинисто-каменисто-щебнистые отложения с содержанием скелета 60-70 \%. На поверхности почвы щебня 30-50 \%, камней 20-30\%. Обеспеченность почвы гумусом варьирует от низкой до средней (содержание гумуса 1,3-2,4 \%). По содержанию подвижного фосфора и калия - обеспеченность средняя: $\mathrm{P}_{2} \mathrm{O}_{5}$ содержится 1,5 мг, $\mathrm{K}_{2} \mathrm{O}-22$ мг на 100 г почвы. Содержание активной извести низкое - 2,4-6,8 \%, при этом реакция почвенной водной суспензии $\mathrm{pH}-8,4$. Засоление по профилю отсутствует, сумма токсичных солей составляет 0,2-0,3 мг-экв. Общая щёлочность невысокая и составляет 0,3 мг-экв., хлора - 0,04-0,06 мг-экв. По механическому составу почва тяжелосуглинистая, физической глины $-56,5 \%$.

Анализ метеорологических условий местности, где был заложены опыты 1 и 2, проводили на основании данных агрометеорологической станции «Никитский сад». Метеоусловия 2016-2017 годов в сравнении со среднемноголетними отличались более высокими среднесуточными температурами воздуха: температура в весенне-летний период была выше среднемноголетних значений на $1,4-2,1{ }^{\circ} \mathrm{C}$, количество выпавших осадков за весенний период превосходило среднемноголетнюю норму на 31,5 мм, а за летний период осадков выпало меньше среднемноголетней нормы на 13,3 мм. Сумма активных температур летом была выше многолетней на $287,7^{\circ} \mathrm{C}$. В целом метеорологические условия за период исследований сложились достаточно благоприятные для вегетации изучаемого сорта. 
Плодоводство и виноградарство Юга России № 59(5), 2019 г.

Агротехнические мероприятия выполнялись согласно «Технологической карте хозяйства» по возделыванию винограда для промышленной переработки. Мероприятия по защите от вредителей и болезней проводились в соответствии с «Планом защитных мероприятий хозяйства».

\section{Схема полевых опытов}

Опыт 1. Плодоносящий виноградник сорта Шардоне, площадь обработки «ПФКлерос» - 0,6 га (2 опытных варианта, эталон Золон, вредный объект - паутинный клещ (Tetranychus urticae Koch.). Учетные - 4 стандартных ряда виноградника по 100 п.м, (100 учётных кустов в каждом), согласно схеме посадки 3,0х1,0 м.

Опыт 2. Плодоносящий виноградник сорта Шардоне, площадь обработки «ПФКлерос» - 0,6 га (2 опытных варианта, эталон фунгицид Топаз, вредный объект - оидиум (Uncinula necator [Schwein] Burr.). Учётные - 4 стандартных ряда виноградника по 100 п.м, (100 учётных кустов в каждом), согласно схеме посадки 3,0х1,0 м.

Схемы полевых опытов № 1, 2.

Применение фунгицидно-акарицидного препарата «ПФКлерос» на плодоносящем винограднике ГУП РК «ПАО «Массандра», сорт Шардоне, 2016-2017 гг.

\begin{tabular}{|c|c|c|c|c|}
\hline Вариант & $\begin{array}{l}\text { Вредный } \\
\text { объект }\end{array}$ & $\begin{array}{l}\text { Кол-во } \\
\text { учетных } \\
\text { кустов } \\
\end{array}$ & Срок внесения препарата & $\begin{array}{c}\text { Норма внесения, } \\
\text { мл/10 л воды }\end{array}$ \\
\hline I & \multirow{4}{*}{ 㝵 } & \multirow{4}{*}{$\begin{array}{l}\text { по } 15 \text { шт. } \\
\text { в варианте }\end{array}$} & \multirow{2}{*}{$\begin{array}{l}\text { 1. Перед цветением } \\
\text { (против клещей) } \\
\text { 2. После цветения } \\
\text { 3. Через } 2 \text { недели после } \\
\text { предыдущей обработки } \\
\text { 4. Через } 2 \text { недели после } \\
\text { предыдущей обработки }\end{array}$} & 40,0 \\
\hline II & & & & 60,0 \\
\hline $\begin{array}{l}\text { Эталон } \\
\text { (Топаз, } \\
\text { Золон) }\end{array}$ & & & $\begin{array}{l}\text { Защитные мероприятия } \\
\text { по плану «Защитных ме- } \\
\text { роприятий хозяйства» }\end{array}$ & $2,0 / 20,0$ \\
\hline Контроль & & & Без обработки & - \\
\hline
\end{tabular}

Примечание: обработка ранцевым опрыскивателем, за эталон взяты: Золон - клещи, Топаз - оидиум. 
Плодоводство и виноградарство Юга России № 59(5), 2019 г.

Обсуждение результатов. Результаты наблюдений за прохождением фенологических фаз растениями винограда сорта Шардоне свидетельствуют о соответствии условий Южного берега Крыма биологическим особенностям сорта. Соответствие природным условиям местности подтверждается сравнительным анализом данных литературных источников [9].

В сроках наступления конкретных фенологических фаз по вариантам опытов у сорта Шардоне различий не было (табл. 1).

Таблица 1 - Фенологические наблюдения (средние значения)

\begin{tabular}{|c|c|c|c|c|c|}
\hline Сорт & $\begin{array}{c}\text { Начало } \\
\text { распускания } \\
\text { глазков }\end{array}$ & $\begin{array}{c}\text { Начало } \\
\text { цветения }\end{array}$ & $\begin{array}{c}\text { Начало } \\
\text { созревания } \\
\text { ягод }\end{array}$ & $\begin{array}{c}\text { Техническая } \\
\text { зрелость }\end{array}$ & $\begin{array}{c}\text { Продукционный } \\
\text { период, дней }\end{array}$ \\
\hline Шардоне & 20.04. & 31.05. & 12.08. & 29.08. & 131 \\
\hline
\end{tabular}

Результаты агробиологических учётов свидетельствуют о близком агротехническом фоне в выборке кустов винограда и о возможности закладки опыта на равных по силе роста кустах. Результаты дисперсионного анализа однофакторного опыта с рендомизированными повторениями, в котором были определены такие агробиологические показатели, как нагрузка на куст, количество неразвившихся, развившихся и плодоносных побегов, соцветий, показали, что различий между вариантами опыта на момент закладки на 5 \% уровне значимости нет (табл. 2).

Таблица 2 - Агробиологические учеты, сорт Шардоне (средние значения)

\begin{tabular}{|c|c|c|c|c|c|c|c|c|}
\hline \multirow[t]{2}{*}{ Вариант } & \multirow{2}{*}{$\begin{array}{c}\text { Нагрузка } \\
\text { куста, } \\
\text { гл. }\end{array}$} & \multicolumn{2}{|c|}{$\begin{array}{c}\text { Нагрузка } \\
\text { побегами } \\
\text { на куст }\end{array}$} & \multicolumn{2}{|c|}{$\begin{array}{c}\text { Плодоносные } \\
\text { побеги }\end{array}$} & \multirow{2}{*}{$\begin{array}{c}\text { Кол-во } \\
\text { соцветий, } \\
\text { шт. }\end{array}$} & \multicolumn{2}{|c|}{ Коэффициенты } \\
\hline & & Шт. & $\%$ & шт. & $\%$ & & $\mathrm{~K}_{1}$ & $\mathrm{~K}_{2}$ \\
\hline I (40 мл/10 л $\mathrm{H}_{2} \mathrm{O}$ ) & 30,2 & 23,3 & 77,2 & 16,1 & 69,1 & 21,8 & 0,94 & 1,35 \\
\hline II (60 мл/10 л $\left.\mathrm{H}_{2} \mathrm{O}\right)$ & 32,7 & 25,1 & 76,8 & 15,2 & 60,6 & 20,0 & 0,72 & 1,32 \\
\hline Контроль & 34,2 & 25,0 & 73,1 & 12,2 & 48,8 & 17,7 & 0,71 & 1,45 \\
\hline $\mathrm{HCP}_{05}$ & 8,89 & 6,18 & - & 5,11 & - & 6,26 & 0,2 & 0,14 \\
\hline
\end{tabular}

В опыте I по испытанию акарицидного действия «ПФКлерос» пороговые значения развития паутинного клеща наблюдались в первой декаде 
Плодоводство и виноградарство Юга России № 59(5), 2019 г.

мая и составили в среднем от 10,6 до 11,1 ед. особи на лист. На момент цветения в контрольном варианте его численность увеличилась до 19,2 особи, а после цветения - на 21 день учёта численность составила 37,1 особи, то есть увеличилась в 3,4 раза.

Численность клещей после первой обработки при норме внесения препарата 40 мл/10 л $\mathrm{H}_{2} \mathrm{O}$ составила 3,2 особи, а при норме внесения 60 мл/10 л $\mathrm{H}_{2} \mathrm{O}$ - 2,9 особи на лист. Биологическая эффективность препарата «ПФКлерос» - 84,2 \% и 85,7 \%, что было в среднем на уровне эталонного препарата Золон $(86,1$ \%). Численность паутинного клеща после второй обработки в вариантах с нормами расхода препарата 40 и 60 мл/10 л $\mathrm{H}_{2} \mathrm{O}$ составила соответственно 3,8 и 3,5 особей на листовую пластинку. Биологическая эффективность - 79,9 и 81,1%, значения близки к эталону Золон. Третья обработка обеспечила достаточно высокую биологическую эффективность при нормах расхода препарата 40 и 60 мл/10 л $\mathrm{H}_{2} \mathrm{O}$ : на уровне 76,3 и 77,1\% при учёте через 14 дней после обработки и 69,2 и 75,1 \% через 21 день. При норме внесения 40 мл/10 л $\mathrm{H}_{2} \mathrm{O}$ эффект уменьшился через 21 день после 3 обработки. При этом биологическая эффективность снизилась с 76,3% до 69,2 \% (табл. 3).

Таким образом, применение препарата «ПФКлерос» фунгицидноакарицидного действия с нормой 40 и 60 мл/10 л $\mathrm{H}_{2} \mathrm{O}$ при средней численности вредоносного объекта (паутинный клещ) обеспечивает эффективное снижение его численности при трехкратной обработке.

Погодные условия вегетации годов исследований для сорта Шардоне в условиях Южнобережного района Крыма были благоприятными для развития такого вредоносного объекта, как оидиум (Uncinula necator [Schwein] Burr.). Данное заболевание в условиях Южного берега Крыма более вредоносно, чем в других регионах страны. Технический сорт Шардоне был выбран для испытания фунгицидного действия препарата «ПФКлерос», поскольку сорт восприимчив к данному заболеванию и требует многократной обработки за сезон. 
Плодоводство и виноградарство Юга России № 59(5), 2019 г.

Таблица 3 - Изучение акарицидного действия препарата «ПФКлерос» (средние значения)

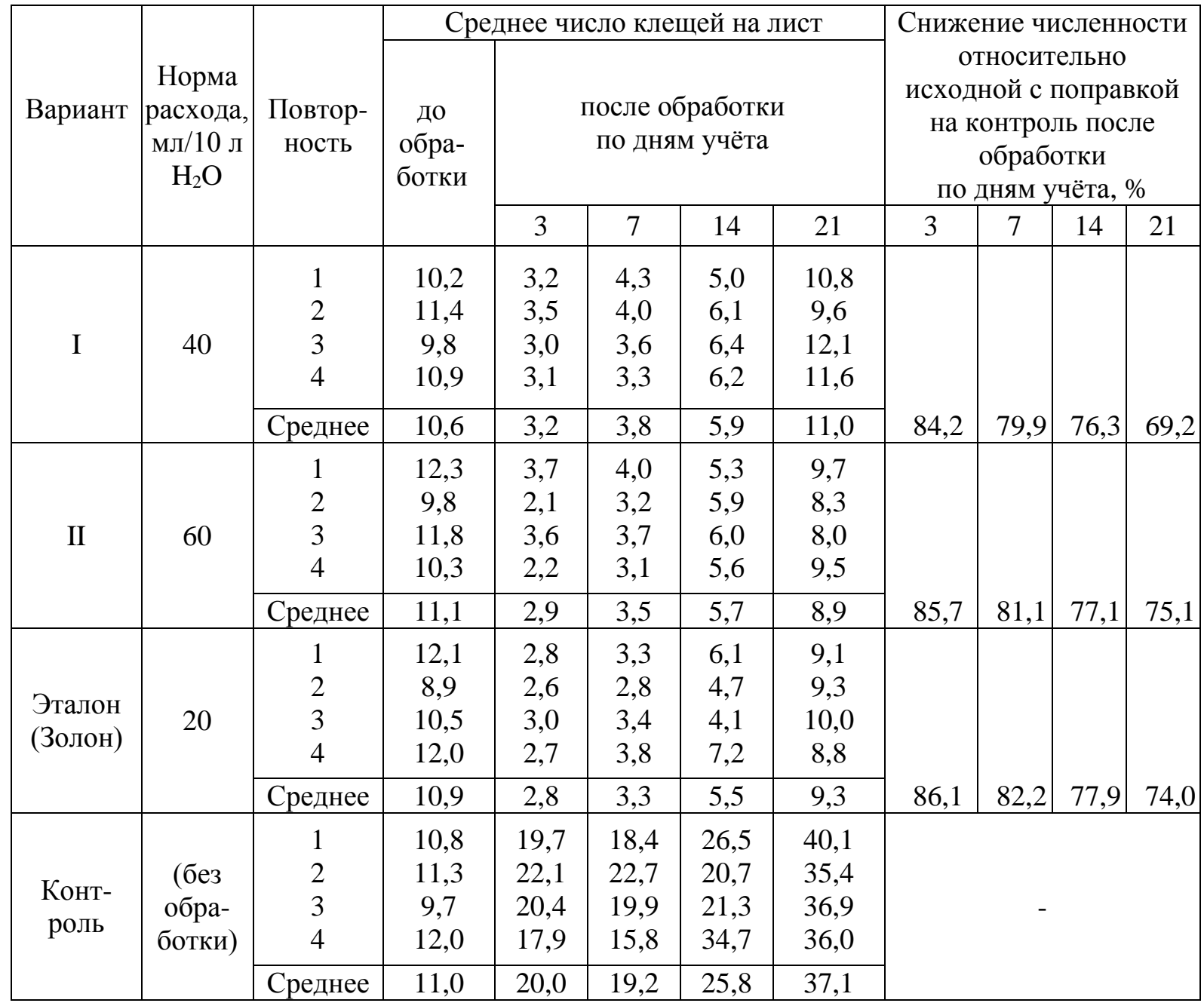

Примечание: опыт производственный - для учета взяты 4 куста, 1 повторность (40 листьев, с каждого куста по 10 листьев в зависимости от яруса).

Начало развития заболевания приходилось на вторую декаду июня, так как погодные условия в это время были благоприятными: резкое повышение температуры воздуха, осадки обильные ливневого характера. При этом распространение оидиума было отмечено в среднем на 8,4 \% растений, а развитие составило 2,0 \%. Первые обработки препаратом проводились во второй половине июня. Последующие - через каждые две недели после предыдущей. В контрольном варианте, где не применялись фунгицидные препараты, распространение и развитие заболевания достигло максимума $(\mathrm{P}-70,8$ \% и $\mathrm{R}-26,5$ \%) во второй половине августа. Урожай винограда с растений данного варианта опыта был не пригоден для его переработки. 
Существенной разницы между вариантами опыта, где испытывались нормы применения фунгицидно-акарицидного препарата «ПФКлерос», не наблюдалось. Биологическая эффективность препарата была на уровне эталона Топаз: через 7 дней после первой обработки эффективность в опытных вариантах при норме 40 мл/10 л воды составила 82,1 \%; при норме 60 мл/10 л воды - 83,3 \%, а у эталона $-84,6$ \%. В последующий учёт через две недели после второй обработки БЭ снизилась до уровня 71,9-73,5 \%. Перед уборкой она составила 71,7-72,8 \%, показания близки к эталону $-73,8 \%$ (табл. 4).

Таблица 4 - Изучение фунгицидного действия препарата «ПФКлерос» (средние значения)

\begin{tabular}{|c|c|c|c|c|c|c|c|c|c|c|c|c|c|c|c|}
\hline \multirow{3}{*}{ 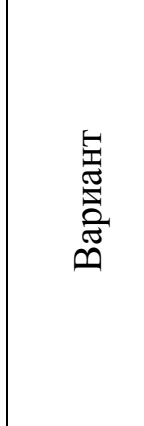 } & \multirow{3}{*}{ 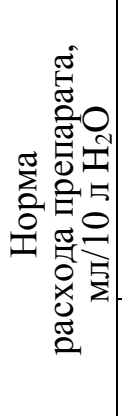 } & \multirow{2}{*}{\multicolumn{2}{|c|}{$\begin{array}{c}\text { До } \\
\text { обработки }\end{array}$}} & \multicolumn{12}{|c|}{ Номер обработки и сроки внесения препарата } \\
\hline & & & & \multicolumn{3}{|c|}{$\begin{array}{l}\text { 1. Перед } \\
\text { цветением }\end{array}$} & \multicolumn{3}{|c|}{$\begin{array}{l}\text { 2. Через } \\
2 \text { недели } \\
\text { после } \\
\text { предыдущей } \\
\text { обработки }\end{array}$} & \multicolumn{3}{|c|}{$\begin{array}{l}\text { 3. Через } \\
2 \text { недели } \\
\text { после } \\
\text { предыдущей } \\
\text { обработки }\end{array}$} & \multicolumn{3}{|c|}{$\begin{array}{l}\text { 4. Перед } \\
\text { уборкой } \\
\text { урожая }\end{array}$} \\
\hline & & $\begin{array}{l}\mathrm{P}, \\
\%\end{array}$ & $\begin{array}{l}\mathrm{R}, \\
\%\end{array}$ & $\begin{array}{l}\mathrm{P}, \\
\%\end{array}$ & $\begin{array}{l}\mathrm{R}, \\
\%\end{array}$ & $\begin{array}{c}\text { БЭ, } \\
\%\end{array}$ & $\begin{array}{l}\mathrm{P}, \\
\%\end{array}$ & $\begin{array}{l}\mathrm{R}, \\
\%\end{array}$ & БЭ, & $\begin{array}{l}\mathrm{P} \\
\%\end{array}$ & $\begin{array}{l}\mathrm{R}, \\
\%\end{array}$ & БЭ, & $\begin{array}{l}\mathrm{P}, \\
\%\end{array}$ & $\begin{array}{l}\mathrm{R}, \\
\%\end{array}$ & $\begin{array}{c}\text { БЭ, } \\
\%\end{array}$ \\
\hline I & 40 & & & 5,4 & 1,4 & 82,1 & 10,3 & 3,5 & 76,5 & 17,1 & 5,2 & 71,9 & 19,4 & 7,5 & 71,7 \\
\hline II & 60 & & & 5,1 & 1,3 & 83,3 & 9,6 & 3,2 & 78,5 & 16,4 & 5,0 & 73,0 & 19,1 & 7,2 & 72,8 \\
\hline $\begin{array}{l}\text { Эталон } \\
\text { (Топаз) }\end{array}$ & 2 & 8,4 & 2,0 & 4,9 & 1,2 & 84,6 & 9,2 & 3,0 & 79,9 & 15,8 & 4,9 & 73,5 & 19,0 & 7,0 & 73,6 \\
\hline $\begin{array}{c}\text { Кон- } \\
\text { троль }\end{array}$ & - & & & 31,1 & 7,8 & - & 42,7 & 14,9 & - & 58,1 & 18,5 & - & 70,8 & 26,5 & - \\
\hline
\end{tabular}

Таким образом, в эпифитотийные годы данная биологическая эффективность будет достаточной в случае увеличения кратности обработок. Применение препарата на сортах винограда, восприимчивых к оидиуму, в Южнобережном районе Крыма необходимо чередовать с более эффективными препаратами или проводить первую обработку при обнаружении эпифитотийного хода развития более эффективными препаратами в борьбе с оидиумом, а в качестве профилактических мер применять фунгицидно-акарицидный препарат «ПФКлерос». 
Плодоводство и виноградарство Юга России № 59(5), 2019 г.

Изучение ростовых процессов в динамике показало, что прирост на учетных кустах винограда Шардоне при применении препарата «ПФКлерос» характеризовался стабильным превышением над контролем таких показателей, как средняя длина побега, площадь листовой поверхности и вызревание побегов. Положительное действие изучаемого препарата выразилось в увеличении средней длины побегов в опытных вариантах по сравнению с контролем на 13,3-25,7 \% (на период третьего и четвертого замеров). Пропорционально длине побегов увеличилась площадь листовой поверхности кустов, значения которой по вариантам опытов превосходили контроль на 14,8-24,4 \%. Степень вызревания прироста в опытных вариантах повысилась на 9,1-18,9 \%. Лучшие показатели прироста виноградного куста и степени его вызревания были в варианте опыта II с нормой внесения препарата «ПФКлерос» - 60 мл на 10 л воды.

Урожай и качество винограда являются основными показателями, характеризующими результаты применяемой агротехники сорта, выращиваемого в той или иной зоне [10-13]. Результаты исследований по изучению действия фунгицидно-акарицидного препарата «ПФКлерос» на урожай сорта Шардоне представлены в таблице 5.

Таблица 5 - Величина и качество урожая сорта Шардоне (средние значения)

\begin{tabular}{|c|c|c|c|c|c|}
\hline \multirow[b]{2}{*}{ Вариант } & \multirow{2}{*}{$\begin{array}{c}\text { Норма расхода } \\
\text { препарата, } \\
\text { мл/10 л } \mathrm{H}_{2} \mathrm{O}\end{array}$} & \multirow{2}{*}{$\begin{array}{c}\text { Урожай } \\
\text { с куста, кг }\end{array}$} & \multirow{2}{*}{$\begin{array}{c}\text { Урожай- } \\
\text { ность, т/га }\end{array}$} & \multicolumn{2}{|c|}{ Массовая концентрация } \\
\hline & & & & $\begin{array}{c}\text { сахаров, } \\
\Gamma / \text { дм }^{3}\end{array}$ & $\begin{array}{c}\text { титр. к-т, } \\
\text { г/дм }\end{array}$ \\
\hline I & 40 & 2,6 & 7,8 & 210 & 4,9 \\
\hline II & 60 & 2,4 & 7,2 & 220 & 4,8 \\
\hline \begin{tabular}{|c|} 
Эталон \\
Топаз/Золон)
\end{tabular} & 2 & 2,5 & 7,5 & 218 & 4,8 \\
\hline Контроль & - & 1,7 & 5,2 & 205 & 5,2 \\
\hline $\mathrm{HCP}_{05}$ & - & 0,77 & 2,99 & 44,6 & 1,23 \\
\hline
\end{tabular}

Примечание: изреженность насаждений на участке составляет 10 \%.

Общее количество кустов согласно схеме посадки кустов - 3000 шт/га.

Установлено, что применение препарата «ПФКлерос» положительно повлияло на величину и качество урожая изучаемого сорта ви- 
Плодоводство и виноградарство Юга России № 59(5), 2019 г.

нограда. Это выразилось в прибавке урожая и улучшении его качественных показателей. Разница по количеству урожая между опытными вариантами и контролем составила от 0,7 до 0,9 кг с куста. Прибавка урожая составила 2,0-2,6 т/га (38,5-50,0\%).

Положительное влияние препарата на качественные показатели винограда сорта Шардоне выразилось в увеличении массовой концентрации сахаров в соке ягод в опытных вариантах по сравнению с контролем от 2,4 до 7,3 \% при снижении количества титруемых кислот, при этом в контрольном варианте наблюдалась потеря урожая от 50 до 61,5 \%.

Bbыводы. По результатам двухлетних исследований подтверждено фунгицидно-акарицидное действие препарата «ПФКлерос» на культуре винограда в условиях Южного берега Крыма, а также его положительное влияние на основные количественные и качественные показатели урожая технического сорта винограда Шардоне.

Снижение численности паутинного клеща при трехкратной обработке виноградника составило от 84,2 \% до 69,2 \% на протяжении всей вегетации (вариант I с нормой расхода препарата 40 мл/10 л $\mathrm{H}_{2} \mathrm{O}$ ) и от 85,7 \% до 75,1 \% (вариант II с нормой расхода препарата 60 мл/10 л $\mathrm{H}_{2} \mathrm{O}$ ), что соответствует результатам, полученным при использовании эталонного препарата Золон (86,1-74,0%). Разница с эталоном незначительна. Биологическая эффективность системы защиты, включающей три обработки против оидиума, составила 7,5 \% (вариант I с нормой расхода препарата 40 мл/10 л $\mathrm{H}_{2} \mathrm{O}$ ) и 7,2 \% (вариант II с нормой расхода препарата 60 мл/10 л $\mathrm{H}_{2} \mathrm{O}$ ), что соответствует результатам, полученным при использовании эталонного препарата Топаз ( $\mathrm{R}=7,0$ \%). Разница с эталоном незначительна.

Обработки препаратом «ПФКлерос» нормой 40 и 60 мл/10 л $\mathrm{H}_{2} \mathrm{O}$, согласно разработанной схеме, способствуют увеличению урожая винограда сорта Шардоне в среднем на 38,5-50,0 \%, при этом прибавка урожая составляет 2,0-2,6 т/га. 
Плодоводство и виноградарство Юга России № 59(5), 2019 г.

Подтверждено положительное влияние изучаемого препарата на показатели качества винограда сорта Шардоне, которое выразилось в увеличении массовой концентрации сахаров в соке ягод от 2,4 до 7,3 \% при снижении количества титруемых кислот. Наибольшая массовая концентрация сахаров была у варианта II - 220 г/дм³ , значения близки к эталону.

Установлено, что обработки препаратом «ПФКлерос» активизируют ростовые процессы: средняя длина побегов увеличилась на 13,3-25,7 \%, площадь листовой поверхности на 14,8-24,4 \% и степень вызревания прироста на 9,1-18,9 \% по сравнению с контролем. Лучшие показатели прироста виноградного куста и степени его вызревания были в варианте опыта II с нормой внесения препарата «ПФКлерос» 60 мл на 10 л воды.

Результаты исследований являются основанием для рекомендации препарата «ПФКлерос» для защитных мероприятий на виноградниках с сохранением продуктивности и качества урожая, стимуляции ростовых процессов и иммуностимуляции виноградных растений.

\section{Литература}

1. Pandeliev S., Angelov L. Study on the Yield and Quality of the Grape Cv. Tempranillo Depending on Loading with Winter Buds // Bulg. J. agr. Sc. - 2005/ - Vol. 11, №3. P. 289-301.

2. Andrea Anesi, Vineyard zone delineation by cluster classification based on annual grape and vine characteristics / Andrea Anesi, Matteo Stocchero, Silvia Dal Santo, Mauro Commisso, Sara Zenoni, Stefania Ceoldo, Giovanni Battista Tornielli, Tracey E. Sebert, Markus Herderich, Mario Perrotti, Flavia Cuzzo //Precision Agriculture, 2017, Volume 18, Issue 4, pp 525-573

3. Ramón Mira de Orduňa, Climate change associated effects on grape and wine quality and production. Food Research International Volume 43, Issue7, August 2010, Pages 1844-1855.

4. Stucklin H. Massnahmen zur Qualitats steigerung beim Gutedel // Bad. Winzer. 2006. - № 5. - P. 27 - 29.

5. Conner P.J. Performance of Muscadine Grape Cultivars in Southern Georgia // J. Am. Pomol. Soc. - 2009. - Vol. 63, № 3. - P. 101 - 107.

6. Jorger V. Ernteschatzung und Ertragsregulierung 2005 // Bad. Winzer. - 2005. № 5 . - P. $35-36$.

7. Friedel M. Zeilenorientirung im Weinbau - Bedeutung fur die Traubenreife // Wissenschaftsmagasin der Forsungsanstalt Geisenheim. - 2012. - Jg. 3, H. 1. - P. 42 - 45.

8. Špánik F. Energetic aspects of the productive potential of grapevine in Malé Karpaty vineyard region / F. Špánik, B. Šiška, Š. Hronský // Hort. Sci. (Prague), 32 (2005): 108-111.

9. Рябов В.А., Опанасенко Н.Е., Антюфеев В.В. Агроклиматологическая оценка условий произрастания плодовых культур в Крыму. Ялта, 2002. 28 с. 
10. Применение комплексного удобрения при посадке саженцев винограда в условиях восточного района Южнобережной зоны Крыма / Н.А. Тихомирова и др. // Русский виноград: сборник научных трудов ФГБНУ ВНИИВиВ им. Я.И. Потапенко. Т. 4. Новочеркасск: ФГБНУ ВНИИВиВ им. Я.И. Потапенко, 2016. С. 99-112.

11. Почвомодифицирующие органо-минеральные удобрения на виноградниках Крыма / М.Р. Бейбулатов и др. // Субтропическое и декоративное садоводство. Сочи: ВНИИЦиСК РАСХН, 2013. Т. 49. С. 306-313.

12. Применение гуминовых препаратов нового поколения на виноградниках Южного берега Крыма / М.Р. Бейбулатов и др. // Проблемы рационального природопользования и пути их решения: сборник материалов Всероссийской науч.-практ. конф., посвящ. 45-летию ФГБОУВО «ДГТУ» (14-16 декабря 2017 г.). Махачкала: Дагестанский государственный технический университет, 2018. С.19-27.

13. Удобрения для внекорневой подкормки на виноградниках Крыма / М.Р. Бейбулатов и др. // Виноградарство и виноделие. Т. 36. Ялта: ВННИИВиВ «Магарач» РАH, 2006. С.49-54.

14. Прогностическое развитие виноградарства Крыма по результатам научных исследований во ВННИИВиВ «Магарач» в 2018 г. / В.В. Лиховской и др. // Научные труды СКФНЦСВВ. Т. 22. Краснодар: СКФНЦСВВ, 2019. С. 68-78

15. Экологическое обоснование формирования фитосанитарно устойчивых многолетних агроценозов / Е.Г. Юрченко и др. // Научные труды СКФНЦСВВ. Т. 23. Краснодар: СКФНЦСВВ, 2019. С. 176-180.

16. Воробьева Т.Н., Белков А.С. Биотрансформация фунгицидов триазольной группы в экосистеме почва-виноград // Агротехнический метод защиты растений от вредных организмов: материалы VIII межд. науч.-практ. конф., посвящ. 95-летию Кубанского государственного аграрного университета (19-23 июня 2017 г.). Краснодар: ФГБОУ ВО «КубГАУ». 2017. С. 90-92.

17. Влияние химической нагрузки на ампелоценоз по показателям фитосанитарного, физиолого-биохимического состояния растений и загрязнения почвы токсичными веществами / М.Е. Подгорная и др. // Научные труды СКФНЦСВВ. Т. 23. Краснодар: СКФНЦСВВ, 2019. С. 189-193.

18. Воробьева Т.Н., Волкова А.А., Ветер Ю.А. Биологизация промышленного возделывания столового винограда в агроусловиях юга Кубани. Краснодар: АльфаПолиграф, 2013. 142 с.

19. Арестова Н.О., Рябчун И.О., Перелетов Э.В. Влияние препарата «Дезавид+» на подавление основных фитопатогенов винограда // Русский виноград: сборник научных трудов ФГБНУ ВНИИВиВ им. Я.И. Потапенко. Т. 4. Новочеркасск: ФГБНУ ВНИИВиВ им. Я.И. Потапенко, 2016. С. 144-151.

20. Доспехов Б.А. Методика полевого опыта. М.: Агропромиздат. 1985. 351 с.

\section{References}

1. Pandeliev S., Angelov L. Study on the Yield and Quality of the Grape Cv. Tempranillo Depending on Loading with Winter Buds // Bulg. J. agr. Sc. - 2005/ - Vol. 11, № 3. P. 289-301.

2. Andrea Anesi, Vineyard zone delineation by cluster classification based on annual grape and vine characteristics / Andrea Anesi, Matteo Stocchero, Silvia Dal Santo, Mauro Commisso, Sara Zenoni, Stefania Ceoldo, Giovanni Battista Tornielli, Tracey E. Sebert, Markus Herderich, Mario Perrotti, Flavia Cuzzo //Precision Agriculture, 2017, Volume 18, Issue 4, pp 525-573

3. Ramón Mira de Orduňa, Climate change associated effects on grape and wine quality and production. Food Research International Vol-ume 43, Issue7, August 2010, Pages 1844-1855. 
4. Stucklin H. Massnahmen zur Qualitats steigerung beim Gutedel // Bad. Winzer. 2006. - № 5. - P. 27 - 29.

5. Conner P.J. Performance of Muscadine Grape Cultivars in Southern Georgia // J. Am. Pomol. Soc. - 2009. - Vol. 63, № 3. - P. $101-107$.

6. Jorger V. Ernteschatzung und Ertragsregulierung 2005 // Bad. Winzer. - 2005. № 5 . - R. $35-36$.

7. Friedel M. Zeilenorientirung im Weinbau - Bedeutung fur die Traubenreife // Wissenschafts magasin der Forsungsanstalt Geisenheim. - 2012. - Jg. 3, H. 1. - P. 42 - 45.

8. Špánik F. Energetic aspects of the productive potential of grape-vine in Malé Karpaty vineyard region / F. Špánik, B. Šiška, Š. Hronský // Hort. Sci. (Prague), 32 (2005): 108-111.

9. Ryabov V.A., Opanasenko N.E., Antyufeev V.V. Agroklimatologicheskaya ocenka uslovij proizrastaniya plodovyh kul'tur v Krymu. Yalta, 2002. $28 \mathrm{~s}$.

10. Primenenie kompleksnogo udobreniya pri posadke sazhencev vinograda v usloviyah vostochnogo rajona Yuzhnoberezhnoj zony Kryma / N.A. Tihomirova i dr. // Russkij vinograd: sbornik nauchnyh trudov FGBNU VNIIViV im. Ya.I. Potapenko. T. 4. Novocherkassk: FGBNU VNIIViV im. Ya.I. Potapenko, 2016. S. 99-112.

11. Pochvomodificiruyushchie organo-mineral'nye udobreniya na vinogradnikah Kryma / M.R. Bejbulatov i dr. // Subtropicheskoe i dekorativnoe sadovodstvo. Sochi: VNIICiSK RASHN, 2013. T. 49. S. 306-313.

12. Primenenie guminovyh preparatov novogo pokoleniya na vinogradnikah $\mathrm{Yu}-$ zhnogo berega Kryma / M.R. Bejbulatov i dr. // Problemy racional'nogo prirodopol'zovaniya i puti ih resheniya: sbornik materialov Vserossijskoj nauch.-prakt. konf., posvyashch. 45-letiyu FGBOUVO «DGTU» (14-16 dekabrya 2017 g.). Mahachkala: Dagestanskij gosudarstvennyj tekhnicheskij universitet, 2018. S.19-27.

13. Udobreniya dlya vnekornevoj podkormki na vinogradnikah Kryma / M.R. Bejbulatov i dr. // Vinogradarstvo i vinodelie. T. 36. Yalta: VNNIIViV «Magarach» RAN, 2006. S.49-54.

14. Prognosticheskoe razvitie vinogradarstva Kryma po rezul'tatam nauchnyh issledovanij vo VNNIIViV «Magarach» v 2018 g. / V.V. Lihovskoj i dr. // Nauchnye trudy SKFNCSVV. T. 22. Krasnodar: SKFNCSVV, 2019. S. 68-78

15. Ekologicheskoe obosnovanie formirovaniya fitosanitarno ustojchivyh mnogoletnih agrocenozov / E.G. Yurchenko i dr. // Nauchnye trudy SKFNCSVV. T. 23. Krasnodar: SKFNCSVV, 2019. S. 176-180.

16. Vorob'eva T.N., Belkov A.S. Biotransformaciya fungicidov triazol'noj gruppy v ekosisteme pochva-vinograd // Agrotekhnicheskij metod zashchity rastenij ot vrednyh organizmov: materialy VIII mezhd. nauch.-prakt. konf., posvyashch. 95-letiyu Kubanskogo gosudarstvennogo agrarnogo universiteta (19-23 iyunya 2017 g.). Krasnodar: FGBOU VO «KubGAU». 2017. S. 90-92.

17. Vliyanie himicheskoj nagruzki na ampelocenoz po pokazatelyam fitosanitarnogo, fiziologo-biohimicheskogo sostoyaniya rastenij i zagryazneniya pochvy toksichnymi veshchestvami / M.E. Podgornaya i dr. // Nauchnye trudy SKFNCSVV. T. 23. Krasnodar: SKFNCSVV, 2019. S. 189-193.

18. Vorob'eva T.N., Volkova A.A., Veter Yu.A. Biologizaciya promyshlennogo vozdelyvaniya stolovogo vinograda v agrousloviyah yuga Kubani. Krasnodar: Al'fa-Poligraf, 2013. $142 \mathrm{~s}$.

19. Arestova N.O., Ryabchun I.O., Pereletov E.V. Vliyanie preparata «Dezavid+» na podavlenie osnovnyh fitopatogenov vinograda // Russkij vinograd: sbornik nauchnyh trudov FGBNU VNIIViV im. Ya.I. Potapenko. T. 4. Novocherkassk: FGBNU VNIIViV im. Ya.I. Potapenko, 2016. S. 144-151.

20. Dospekhov B.A. Metodika polevogo opyta. M.: Agropromizdat. 1985. $351 \mathrm{~s}$. 